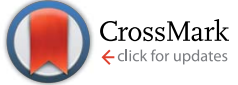

Cite this: RSC Adv., 2015, 5, 40036

\title{
Biomagnification of mercury in mollusks from coastal areas of the Chinese Bohai Seat
}

\author{
Mei Meng, ${ }^{a}$ Jian-bo Shi, ${ }^{\text {abb }}$ Cheng-bin Liu, ${ }^{a} \mathrm{Na}-\mathrm{li} Z \mathrm{Zhu},{ }^{a}$ Jun-juan Shao, ${ }^{a} \mathrm{Bin} \mathrm{He}^{a}$ \\ Yong Caibc and Gui-bin Jiang ${ }^{a}$
}

The multiple recognized mollusk species are usually regarded as one group lying at the second trophic level in the marine ecosystem. As a result, the virtual resolution of $\mathrm{Hg}$ uptake and transfer processes that occur in different mollusks would be overlooked. In this work, the concentrations of total mercury (THg) and methylmercury $(\mathrm{MeHg}), \delta^{15} \mathrm{~N}, \delta^{13} \mathrm{C}$ and lipid contents were comprehensively analyzed in 11 mollusk species collected from the Chinese Bohai Sea during 2007-2012. The contents of THg and MeHg were in the range $27.2-461.1$ and $2.1-295.5 \mu \mathrm{gg}^{-1}$, respectively. The trophic levels (TLs) were in the range 1.99-4.02. The biomagnification of $\mathrm{Hg}$ was evident from the significant positive correlations between $\mathrm{Hg}$ contents and TLs, and from the trophic magnification factors (TMFs). MeHg is the main species of $\mathrm{Hg}$ magnification in mollusks, while growth dilution occurs in the trophic transfer of inorganic mercury $(\mathrm{lHg})$. TLs showed a greater effect on Hg levels in mollusks than lipid contents.

Received 15th February 2015 Accepted 27th April 2015

DOI: $10.1039 / \mathrm{c} 5 \mathrm{ra02919h}$

www.rsc.org/advances mollusk species are grouped in the large-scale marine food web analyses, the virtual resolution of $\mathrm{Hg}$ uptake and transfer processes that occur at the low trophic level organisms would be overlooked. A recent study has revealed significant $\mathrm{Hg}$ biomagnification in marine zooplankton food webs collected from Hudson Bay, Canada. ${ }^{8}$ It still remains unknown whether the biomagnification of $\mathrm{Hg}$ occurs in low trophic level mollusks. Therefore, it is imperative to investigate the trophic transfer of $\mathrm{Hg}$ in mollusk food webs.

Bioaccumulation and biomagnification of $\mathrm{Hg}$ in marine organisms have drawn scientists' attention for several decades. WHO (1976 and 1990) reported concentrations of methylmercury $(\mathrm{MeHg})$ in predatory fish species reaching up to $10^{6}$ times higher than concentrations of $\mathrm{Hg}$ in ambient water., ${ }^{\mathbf{9} 10} \mathrm{MeHg}$ was noted to be the dominant form of $\mathrm{Hg}$ accumulated by organisms at higher trophic levels (TLs), accounting for 85-95\% of total mercury (THg). ${ }^{11-13}$ Studies on mechanisms found that lipophilic $\mathrm{MeHg}$ passed easily through intestinal membrane into blood, and the efficient assimilation of $\mathrm{MeHg}$ to fat and muscle and the lack of elimination leaded to increasing $\mathrm{MeHg}$ levels with age and size of fish. ${ }^{14}$ Biomagnification of $\mathrm{Hg}$ along food chains has been or is still widely investigated from different aspects and in different regions. ${ }^{15-18}$ Trophic magnification factors (TMFs) are usually used as approved evidence for biomagnification in a food web. ${ }^{19}$ Recently, TMFs are suggested to be calculated separately for poikilotherms (including mollusks) and homeotherms due to their different biomagnification rates resulted from differences in energy requirements and abilities to biotransform pollutants. ${ }^{20}$

The long-term study on the fishery ecosystem structure of Chinese Bohai Sea showed that the dominant large-size and 
high economic value fishes have been replaced by the shortlived and small-sized pelagic fishes since the 1980s, which have been recently replaced by invertebrates. ${ }^{21}$ Current fishery community in Bohai Sea are characterized as smaller, younger, low-biomass, low-quality and low-value varieties, with crustaceans, shellfish and jellyfish as the main fishing species. ${ }^{22}$ According to the statistics on the fishing structure of the Bohai Sea and Yellow Sea in China, the total catch of shellfish was 403100 tons in the year 2009 , accounting for about $10 \%$ of total fishing output from this area. ${ }^{22}$ The reduced biomass of largesized fish has shortened the food chain in the Bohai Sea. The mean trophic level has declined from 4.06 in 1959-1960 to 3.41 in 1998-1999, and this decline was faster than that of the global catch. ${ }^{21}$ As a result, mollusks are taking up an increasingly important proportion in the large-scale marine food webs of this area, and have gradually constituted an important seafood source of human $\mathrm{Hg}$ exposure. Using mollusks as bioindicators would not only help to reflect the contamination status and estimate the human $\mathrm{Hg}$ exposure, but also provide information for coastal management and fishery adjustment. Moreover, perched on the bottom of the coastal waters and lying in the low trophic level of marine food webs, mollusks have great potential in connecting the land-based river discharges of $\mathrm{Hg}$ with top predators. Thus, mollusks play essential roles in the biogeochemical cycling of $\mathrm{Hg}$ in coastal regions, especially in the Chinese Bohai Sea.

The aim of this work was to study the accumulation and magnification of $\mathrm{Hg}$ in marine mollusk food webs through the detection of $\delta^{15} \mathrm{~N}$ and $\delta^{13} \mathrm{C}$. The effects of trophic level and lipid contents on the levels and species of $\mathrm{Hg}$ in mollusks were discussed in detail. The possibility of using mollusk as bioindicators for $\mathrm{Hg}$ monitoring was also evaluated through the calculation of bioaccumulation factors (BAFs).

\section{Materials and methods}

\subsection{Sample collection and preparation}

The Bohai Sea, surrounded by highly industrialized cities, consists of the Liaodong, Bohai, and Laizhou bays and the inner region. It receives a large amount of fresh water from over 40 rivers, among which the Liaohe, Luanhe, Haihe and Yellow Rivers are the four major ones. With an average water depth of $18 \mathrm{~m}$ and coastal line of nearly $3800 \mathrm{~km}$, the Bohai Sea is the largest semi-enclosed inner shelf sea in China and the water change is very slow. Once contaminated, the Bohai Sea needs a long time to resume the water quality. Fig. 1 shows the map of the 9 coastal cities along Bohai Sea, including Beidaihe, Dalian, Huludao, Penglai, Shouguang, Tianjin, Weihai, Yantai and Yingkou. The mollusk samples were collected from the coastal areas near these nine cities. The sampling sites involve the nearshore areas of four provinces in the Bohai Sea Rim Economic Zone.

The sampling activities were carried out annually from July to August during 2007-2012, except for the year 2008 when the sampling was not conducted. Eleven species of mollusks, including nine species of bivalves, Amusium veneriformis (Amu), Chlamys farreri (Chl), Cyclina sinensis (Cyc), Mactra veneriformis
(Mac), Meretix meretrix (Mer), Mya arenaria (Mya), Mytilus edulis (Myt), Crassostrea talienwhanensis (Ost) and Scapharca subcrenata (Sca), and two species of gastropods, Neverita didyma (Nev) and Rapana venosa (Rap), were selected (Table S1†). The collected mollusks were transported to the laboratory on ice and cleaned by tap water and ultrapure water $(18.2 \mathrm{M} \Omega)$ in the laboratory. The soft tissue of the mollusks was excised with stainless steel scalpel blades and thoroughly rinsed with ultrapure water to remove extraneous impurities. For each sample, about 500-1000 $\mathrm{g}$ of wet soft tissue, consisting of 3-30 individuals, was homogenized in a blender to guarantee enough sample mass. Since these individuals of each sample were collected from the same place at the same time and were similar in size, the contents of total mercury ( $\mathrm{THg}$ ), methylmercury $(\mathrm{MeHg})$ and inorganic mercury ( $\mathrm{IHg}$ ) could be regarded as the same. The homogenized samples were then freeze-dried at -50 ${ }^{\circ} \mathrm{C}$ (Alpha 1-2 LD plus, Christ, Germany) and ground to powder. The samples were stored at $-20{ }^{\circ} \mathrm{C}$ for further analysis. A total of 431 soft tissue samples were obtained and analyzed.

\subsection{Hg analysis}

For total mercury (THg) analysis, a Hydra-C mercury analyzer (Teledyne Leeman Labs, USA) following USEPA method 7473 (ref. 23) was used. For MeHg analysis, the MERX Automatic Methylmercury System (Brooks Rand Laboratories, USA) following USEPA method 1630 (ref. 24) was adopted. Concentrations of inorganic mercury ( $\mathrm{IHg}$ ) were calculated as the concentration of $\mathrm{THg}$ minus that of $\mathrm{MeHg}$. The detailed information for $\mathrm{Hg}$ analysis is provided in ESI. $\dagger$

\subsection{Stable nitrogen and carbon isotope analysis}

$\delta^{15} \mathrm{~N}$ and $\delta^{13} \mathrm{C}$ were determined with a Thermo DELTA $\mathrm{V}$ Advantage isotope ratio mass spectrometer interfaced to a Flash EA1112 HT elemental analyzer (Thermo Fisher, USA). Atmospheric nitrogen $\left(\mathrm{N}_{2}\right)$ and Pee Dee Belemnite (PDB) were used as standards for the calculations of $\delta^{15} \mathrm{~N}$ and $\delta^{13} \mathrm{C}$, respectively. The variations of ${ }^{15} \mathrm{~N}$ versus ${ }^{14} \mathrm{~N}$ and ${ }^{13} \mathrm{C}$ versus ${ }^{12} \mathrm{C}$ are expressed as $\%$ deviations relative to the reference standards in $\delta$ unit according to:

$$
\begin{aligned}
& \delta^{15} \mathrm{~N}(\%)=\left[\left(R_{\text {sample }} / R_{\text {standard }}\right)-1\right] \times 1000 \\
& \delta^{13} \mathrm{C}(\%)=\left[\left(R_{\text {sample }} / R_{\text {standard }}\right)-1\right] \times 1000
\end{aligned}
$$

where $R$ is the corresponding ratio of ${ }^{15} \mathrm{~N} /{ }^{14} \mathrm{~N}$ or ${ }^{13} \mathrm{C} /{ }^{12} \mathrm{C}$. The analytical precisions for $\delta^{15} \mathrm{~N}$ and $\delta^{13} \mathrm{C}$ were $\pm 0.2 \%(n=5)$ and $\pm 0.1 \%$ o $(n=5)$, respectively.

\subsection{TL and TMF calculations}

Trophic levels (TLs) were calculated for mollusk samples based on the measured nitrogen isotope ratios using the following equation: ${ }^{19,25}$

$$
\mathrm{TL}=\left(\delta^{15} \mathrm{~N}_{\text {consumer }}-\delta^{15} \mathrm{~N}_{\text {zooplankton }}\right) / 3.8+2
$$




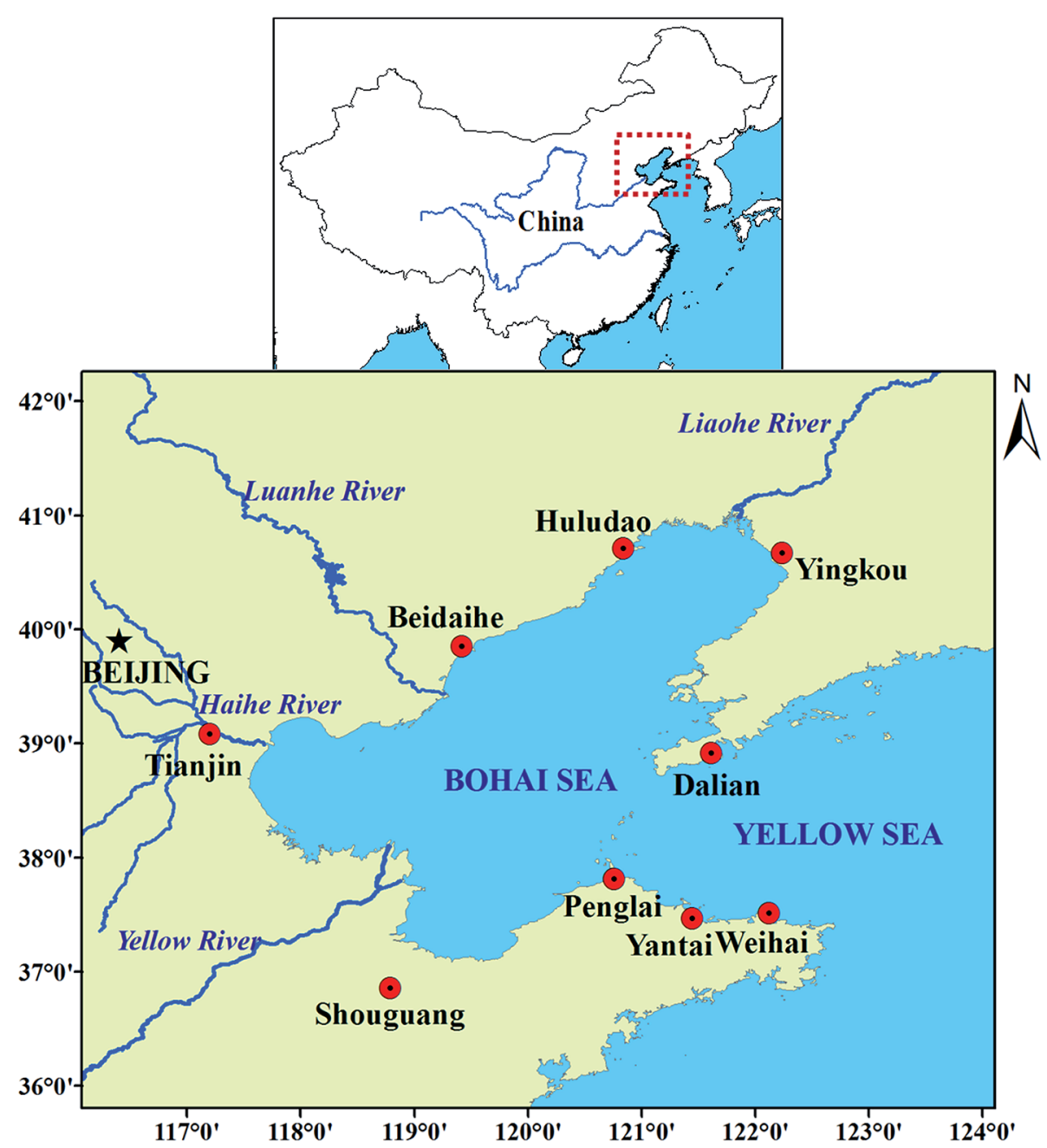

Fig. 1 Map of the sampling area.

Trophic magnification factors (TMFs) were computed based on the regression of $\mathrm{Hg}$ concentration versus $\mathrm{TL}$ according to the following equations: ${ }^{19}$

$$
\begin{aligned}
\log [\mathrm{Hg} \text { concentration }] & =b \times \mathrm{TL}+\text { constant; } \\
\mathrm{TMF} & =10^{b}
\end{aligned}
$$

\subsection{Quality control and statistical analysis}

For the analytical quality control, certified reference materials (CRMs), sample replicates and reagent and method blanks were conducted in the whole procedure. The detailed information of the CRMs and the obtained results are shown in Table S2. $\dagger$ The relative standard deviations (RSDs) for triplicate samples analysis were in the range $0.6-11.8 \%$ and $3.2-10.6 \%$ for $\mathrm{THg}$ and $\mathrm{MeHg}$, respectively.

The map of sampling sites was drawn using software ArcGIS 10. Statistical analysis of the data was accomplished with Origin 8.0 and SPSS 20.0 software. A Kolmogorov-Smirnov test was used to check the normality of the obtained data. One-way
ANOVA, $t$-test and hierarchical cluster analysis were conducted to assess the significant differences of $\mathrm{Hg}$ accumulation in mollusks.

\section{Results and discussion}

\subsection{Comparisons among years, locations and mollusk species}

Concentrations of $\mathrm{THg}, \mathrm{MeHg}$ and percentages of $\mathrm{MeHg}$ in $\mathrm{THg}$ (\%MeHg) in all mollusk samples $(n=431)$ are summarized in Table S3. $\dagger$ Overall, the concentrations of $\mathrm{THg}$ and $\mathrm{MeHg}$ were in the ranges $27.2-461.1$ and $2.1-295.5 \mu \mathrm{g} \mathrm{kg}^{-1}$, with a mean of 99.4 and $45.1 \mu \mathrm{g} \mathrm{kg}{ }^{-1}$, respectively. The median values for both $\mathrm{THg}$ and $\mathrm{MeHg}$ were less than the mean values, indicating that most of the concentrations were distributed at the lower level of the range. The concentrations of both $\mathrm{THg}$ and $\mathrm{MeHg}$ in mollusks were below the maximum permissible limit in China of $500 \mu \mathrm{g} \mathrm{kg}{ }^{-1}$ for MeHg in seafood. ${ }^{26}$ As shown in Table S4, $\dagger$ the mean $\mathrm{THg}$ and $\mathrm{MeHg}$ levels in mollusks from Chinese Bohai Sea were obviously lower than those reported for mollusks in USA, Mexico, French, Italy and Cuba, while similar to those found in Brazil, Adriatic Sea, 
Ionian Sea, Baltic Sea and Mediterranean Sea, and a bit higher than those in West Greenland, Turkey, Iran and Korea. These results suggest a relatively low level of $\mathrm{Hg}$ contamination in mollusks from Chinese Bohai Sea, which could possibly be attributed to the short growing and accumulation period of mollusks resulted from frequent fishing. Studies have found an increasing pattern of $\mathrm{Hg}$ accumulation with size in mollusks from highly contaminated areas. ${ }^{27,28}$ According to our previous study in 2002, Rapana venosa (Rap) collected from Huludao also showed uplifted trends with size, and mollusks collected in this study are comparatively smaller in size. ${ }^{29}$ However, comparing with other regions in China, concentrations of $\mathrm{Hg}$ in this study were obviously higher than those in mollusks from coastal areas of Guangdong and east coasts of Hong Kong (Table S4 $\dagger$ ). Our previous study in 2002 also found $\mathrm{Cd}, \mathrm{Cu}$ and $\mathrm{Zn}$ contents in some gastropods and oysters exceeding the maximum permissible levels recommended by WHO. ${ }^{7}$ These results indicated a certain degree of heavy metal contamination in Bohai Sea area. The concentrations of $\mathrm{THg}$ and $\mathrm{MeHg}$ in all mollusk samples showed a significantly positive correlation $(R=0.776, P<0.001$, Fig. S1 $\dagger)$.

The boxplots for the temporal and spatial variations of $\mathrm{THg}$ and $\mathrm{MeHg}$ in mollusks are shown in Fig. S2 and S3, $\uparrow$ respectively. Except for a slight fluctuation, no significant time trends were found in both $\mathrm{THg}$ and $\mathrm{MeHg}$ levels during this period of six years (Fig. S2 $\dagger$ ), indicating a relatively stable contamination situation in this region. As for the sampling sites, the mollusks collected from Penglai showed slightly higher concentrations of THg than those from Beidaihe, Weihai, Yantai and Yingkou (one-way ANOVA, $P<0.05$ ), and higher levels of $\mathrm{MeHg}$ than those from Yingkou $(P<0.01)$ (Fig. S3†). This is probably attributed to the paper mill industry and the gold mines located in the adjacent area of Penglai. ${ }^{29}$ Wastewater from the paper mill is discharged into Bohai Sea with no disposal, and gold extracting activities using gold-mercury amalgam method in the gold mines lead to the local $\mathrm{Hg}$ contamination in air, river and soil, with $\mathrm{Hg}$ finally converging into Bohai Sea. ${ }^{29}$

Fig. 2 compares the concentrations of $\mathrm{THg}$ and $\mathrm{MeHg}$ in the 11 mollusk species. Obviously, the gastropod species (Nev and Rap) contained significantly higher levels of $\mathrm{THg}$ and $\mathrm{MeHg}$ than the bivalve species ( $t$-test, $P<0.01)$. In order to further compare the accumulation ability for $\mathrm{MeHg}$ of the different mollusk species, the percentages of $\mathrm{MeHg}$ in $\mathrm{THg}(\% \mathrm{MeHg})$ were then calculated. As shown in Table S3 and Fig. S4, $\dagger$ the mean \%MeHg was the highest in Rap (65.8\%) and the next higher in Nev (57.3\%), being significantly different comparing to the nine bivalve species (oneway ANOVA, $P<0.05)$. The mean \%MeHg in Ost $(49.5 \%)$ was slightly lower than that in Rap $(P<0.05)$, but significantly higher than those in Myt (21.3\%) and Sca $(21.1 \%)(P<0.05)$. These results indicate that the gastropod species had higher ability in the accumulation of $\mathrm{MeHg}$ than the bivalve species, and Rap was the highest among the selected species. Among the bivalve species, Ost had a relatively higher ability to accumulate $\mathrm{MeHg}$.

\subsection{Biomagnification of $\mathrm{Hg}$ in mollusk food webs}

Nitrogen isotope ratios $\left(\delta^{15} \mathrm{~N}\right)$ are often determined to identify trophic position of biota in aquatic environment and have been widely used in studying the biomagnification of pollutants through food chain. ${ }^{8,30}$ In this work, $\delta^{15} \mathrm{~N}$ and $\delta^{13} \mathrm{C}$ in mollusk samples collected in 2009 and $2012(n=175)$ ranged from 4.23$11.94 \%$ and -24.40 to $-16.66 \%$, respectively. The calculated TLs for all mollusks were in the range 1.99-4.02 (Table S1 $\dagger$ ), which is consistent with the literature. ${ }^{31}$ Among the 11 species, the predatory gastropods Rap $(3.33 \pm 0.28)$ and Nev $(3.28 \pm$ 0.19) showed higher TLs than the bivalve species, and the concentrations of $\mathrm{THg}$ and $\mathrm{MeHg}$ in both Rap and Nev were also higher than in bivalves (Table S1 $\dagger$ ). Mer had the lowest average concentrations of $\mathrm{THg}$ and $\mathrm{MeHg}$, as well as the lowest $\mathrm{TL}$ $(2.61 \pm 0.74)$.

In order to explore whether the biomagnification of $\mathrm{Hg}$ occurred in the marine mollusk food web, the correlations between $\mathrm{Hg}$ concentration (including $\mathrm{THg}, \mathrm{MeHg}, \mathrm{IHg}$ and \% $\mathrm{MeHg}$ ) and TL were performed (Fig. 3). Significant positive linear relationships were found between THg and TL $(R=0.646$, $P<0.05), \mathrm{MeHg}$ and TL $(R=0.714, P<0.05)$, and \% MeHg and TL $(R=0.677, P<0.05)$, indicating potential trophic transfer and biomagnification of $\mathrm{Hg}$ in mollusk food webs. This relationship is different from that of some persistent organic pollutants (POPs) in mollusks collected from the same area, in which negative correlations were found, implying potential trophic dilution rather than magnification. ${ }^{25,32-34}$ The correlation between $\mathrm{IHg}$ and TL was not statistically significant $(R=$ $0.162, P=0.635$ ), although the concentration of IHg was slightly decreased with TL (Fig. 3).

Trophic magnification factors (TMFs), which are usually used as approved evidence for biomagnification in a food web, were further calculated from the slope of the regression of $\mathrm{Hg}$ concentration $v s$. trophic level. The relations between $\log [\mathrm{Hg}]$ and TL and the results of calculated TMFs are shown in Fig. S5 $\dagger$ and Table 1, respectively. The TMFs for both $\mathrm{THg}$ (1.20) and $\mathrm{MeHg}$ (1.85) were greater than 1, demonstrating the biomagnification of $\mathrm{THg}$ and $\mathrm{MeHg}$ in the mollusk food web. Moreover, the TMFs for $\mathrm{MeHg}$ were much higher than those for $\mathrm{THg}$, suggesting that $\mathrm{MeHg}$ is the main form of $\mathrm{Hg}$ magnifying in mollusks. This conclusion is further confirmed with the low TMFs for IHg (0.78). This result is in agreement with other studies on mercury magnification in marine zooplankton food webs, such as the recent study in Hudson Bay. ${ }^{8}$

Fig. 4 shows the relationships between $\mathrm{MeHg}$ and $\mathrm{IHg}$ contents and $\delta^{15} \mathrm{~N}$. The concentrations of $\mathrm{IHg}$ decreased significantly $(\beta=-3.2, R=0.176, P<0.05 ; \beta$ : slope) over the range of $\delta^{15} \mathrm{~N}$ represented by the mollusks in the entire data set, while the concentrations of $\mathrm{MeHg}$ increased significantly $(\beta=$ $7.9, R=0.294, P<0.001)$. As shown in Fig. S6, $\uparrow$ the concentrations of $\mathrm{THg}$ increased with $\delta^{15} \mathrm{~N}(\beta=4.7, R=0.145, P=0.055)$, but not so significantly as $\mathrm{MeHg}$. Not surprisingly, \% $\mathrm{MeHg}$ increased with $\delta^{15} \mathrm{~N}(\beta=4.7, R=0.336, P<0.001)$. All of these results indicate that the concentrations and percentages of $\mathrm{MeHg}$ increased more significantly with the increasing of mollusk TLs, accompanied by the decreased uptake and/or retention of $\mathrm{IHg}$. Therefore, $\mathrm{MeHg}$ appears to be an efficiently retained form of $\mathrm{Hg}$ in mollusks with progression up the food web, while IHg seems to be more readily cleared from the mollusks. It should be noted that the body size of mollusks may 


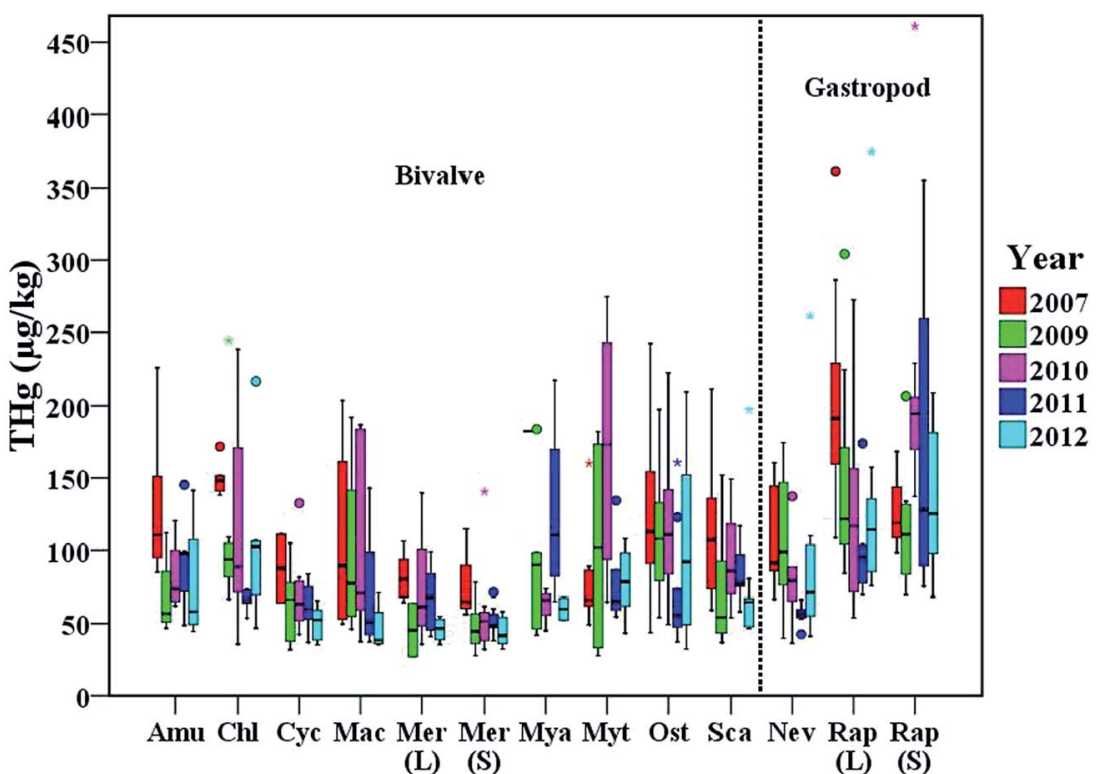

(L) (S)

(L) (S)

\section{Species}

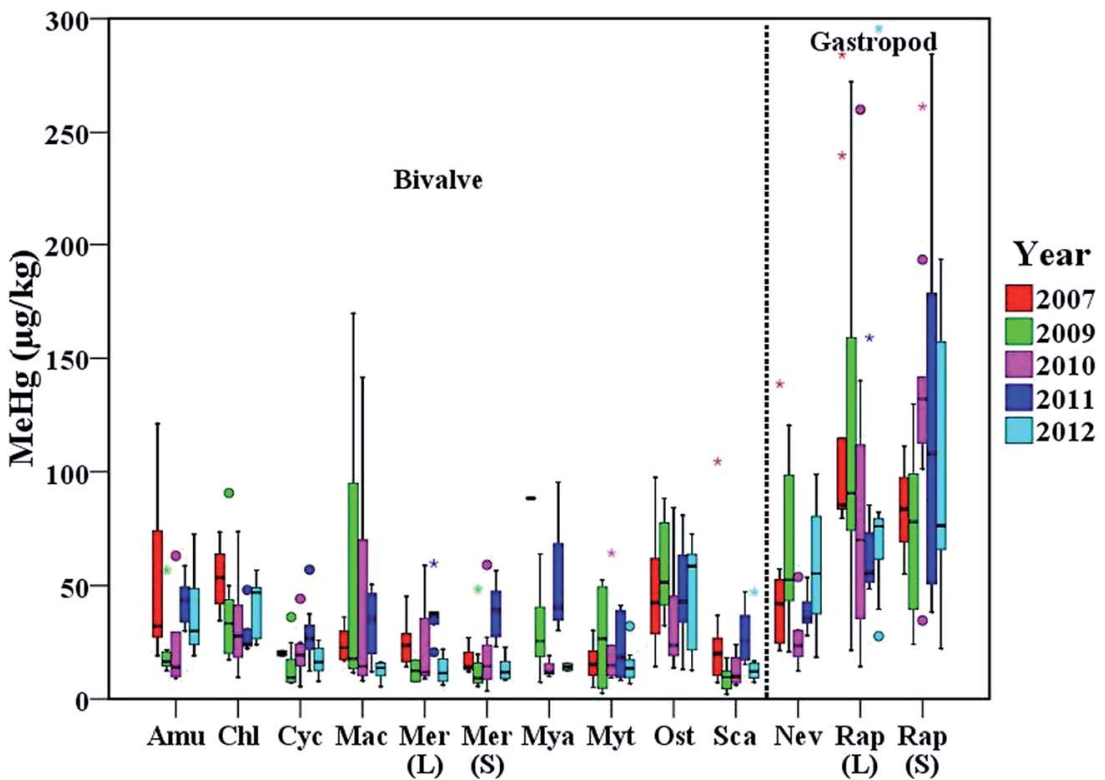

Species

Fig. 2 Boxplots of THg and MeHg in 11 mollusk species during 2007-2012.

also increase with $\delta^{15} \mathrm{~N}$ and the process of growing up of mollusks could show distinct effects on the uptake and retention of different $\mathrm{Hg}$ species. Growth dilution could occur with increasing TLs in the trophic transfer of IHg in mollusks, which would then influence the accumulation trends of $\mathrm{THg}$. It was shown that $\delta^{15} \mathrm{~N}$ in zooplanktons increased with body size, in a study of investigating the trophic transfer of POPs where zooplanktons were fractionated by size. ${ }^{35}$

Over the range of $\delta^{13} \mathrm{C}$ represented by the collected mollusks, the concentrations of $\mathrm{THg}$ were observed to increase $(\beta=4.6, R$ $=0.116, P=0.268)$, and $\mathrm{MeHg}$ concentrations increased more significantly $(\beta=6.5, R=0.211, P<0.05)$ in comparison to $\mathrm{THg}$.
Differently, the concentrations of IHg were found to decrease with $\delta^{13} \mathrm{C}(\beta=-1.9, R=0.080, P=0.446)$. The correlation between $\mathrm{MeHg}$ concentration and $\delta^{13} \mathrm{C}(P<0.05)$ was more significant than those between $\mathrm{THg}$ concentration and $\delta^{13} \mathrm{C}(P=$ $0.268)$ and between $\mathrm{IHg}$ concentration and $\delta^{13} \mathrm{C}(P=0.446)$. In other words, $\mathrm{MeHg}$ in mollusks had significantly positive correlations with enriched $\delta^{13} \mathrm{C}$ values, and $\mathrm{IHg}$ had great relationship with depleted $\delta^{13} \mathrm{C}$ values. Enriched $\delta^{13} \mathrm{C}$ values in marine organisms have been found to correlate with marine organic carbon, while the depleted values were associated with terrigenous organic carbon (via river discharges; inferred from $\left.\delta^{13} \mathrm{C}\right) .^{36}$ It could thus be speculated that the higher $\mathrm{MeHg}$ 

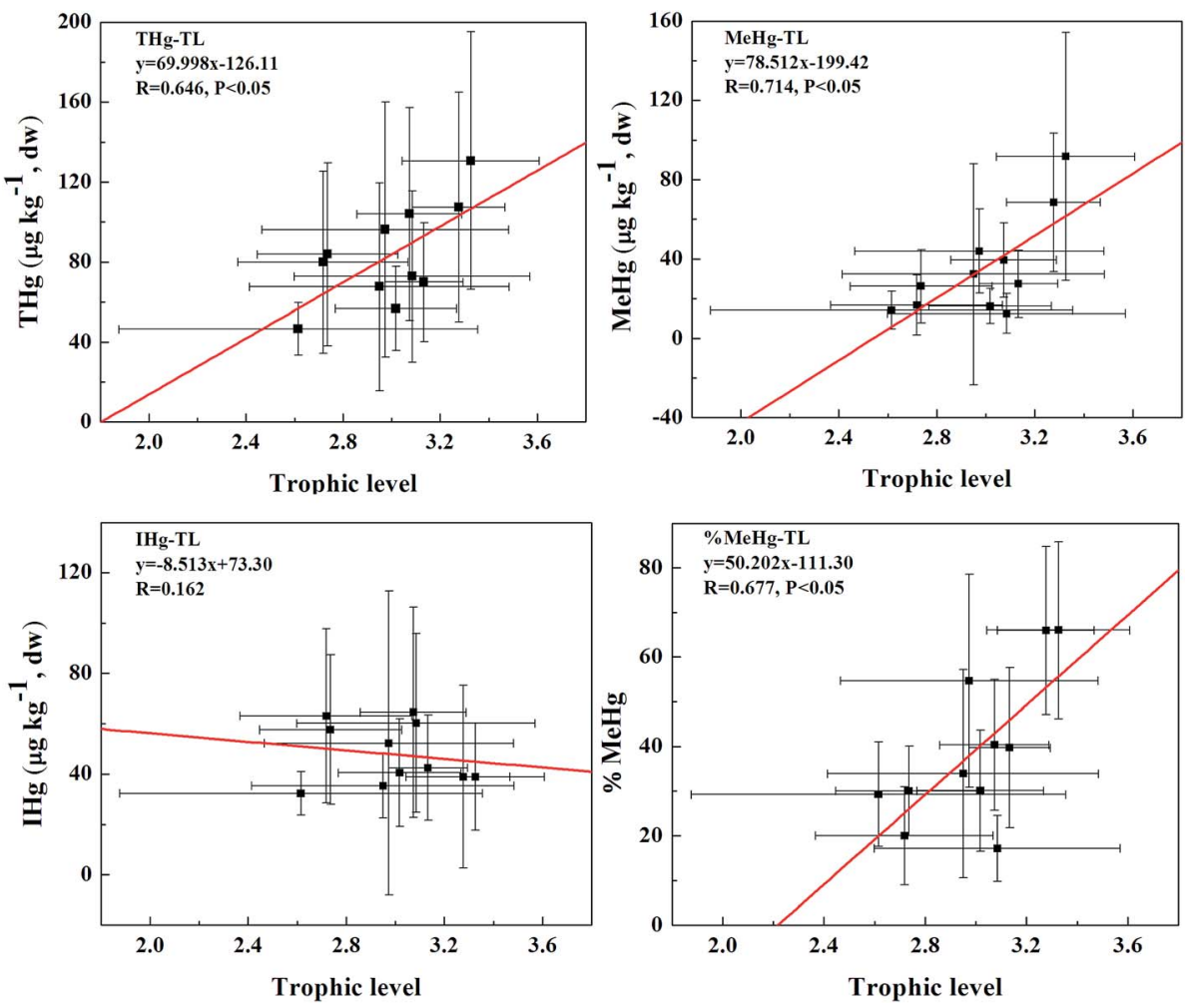

Fig. 3 Relations between concentrations of $\mathrm{THg}, \mathrm{MeHg}, \mathrm{IHg}$ and \% $\mathrm{MeHg}$ and trophic level (TL).

Table 1 Trophic magnification factors (TMF) of THg, MeHg and IHg in mollusks

\begin{tabular}{llll}
\hline Hg species & $b^{a}$ & $p$-value & \\
\hline $\mathrm{THg}$ & 0.080 & 0.042 & $\mathrm{TMF}^{b}$ \\
$\mathrm{MeHg}$ & 0.266 & $1.25 \times 10^{-4}$ & 1.20 \\
$\mathrm{IHg}$ & -0.108 & 0.025 & 1.85 \\
& & & 0.78
\end{tabular}

${ }^{a} \log [\mathrm{Hg}$ concentration $]=b \times \mathrm{TL}+$ constant. ${ }^{b} \mathrm{TMF}=10^{b}$.

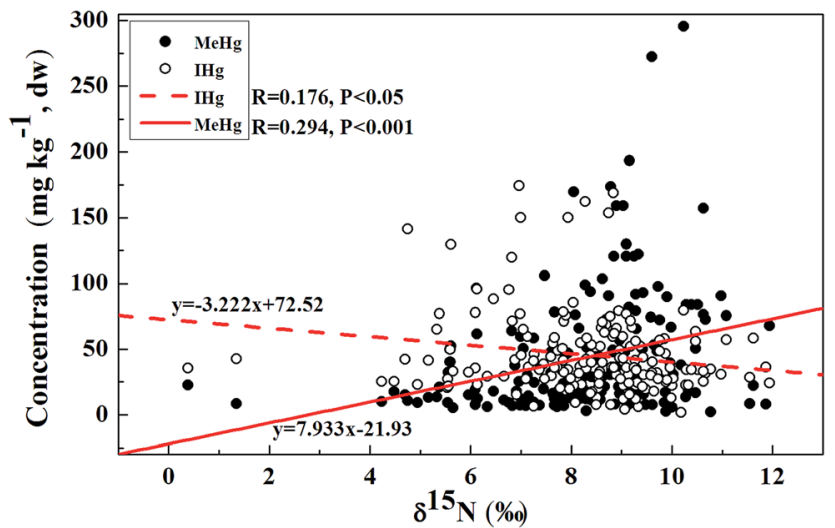

Fig. 4 Relations between concentrations of $\mathrm{MeHg}$ and $\mathrm{IHg}$ and $\delta^{15} \mathrm{~N}$.

concentrations in mollusks were largely related to the methylation/demethylation process associated with dissolved marine organic carbon, while the IHg concentrations could be attributed to the influence of terrigenous organic carbon. Previous studies have found that the dissolved organic carbon (DOC) could bring about the photo-induced methylation of $\mathrm{Hg}^{2+}$ in water, ${ }^{37}$ and the photo-demethylation rate and extent of $\mathrm{MeHg}$ was also affected by DOC. ${ }^{38}$ Hence, DOC may play an important role in the accumulation of $\mathrm{MeHg}$ in mollusks, although microbial methylation of $\mathrm{Hg}^{2+}$ in sediment by microorganisms such as sulfate-reducing bacteria (SRB) was the commonly regarded source of $\mathrm{MeHg}$ to aquatic organisms. Due to the complex equilibrium between $\mathrm{MeHg}$ and $\mathrm{IHg}$ in natural aquatic ecosystems, more research is needed to identify the source and accumulation pathway of $\mathrm{MeHg}$ in mollusks and the carbon source may provide useful information.

Depleted $\delta^{13} \mathrm{C}$, resulted from land-based river inputs, has been found at some coastal regions. ${ }^{39}$ The $\delta^{13} \mathrm{C}$ values in the surface sediments from Chinese Bohai Sea were in the range -26.00 to $-22.10 \%$, with a mean of $-23.10 \%$, reflecting a significant effect of terrigenous organic carbon. ${ }^{\mathbf{4 0}}$ The landbased organic carbon source accounted for 30.7-85.7\% (mean: $43.7 \%$ ) of the total terrigenous organic carbon in recent years, with Yellow River input as the largest contributor. ${ }^{40}$ Since increased terrigenous organic carbon has been reported to associate with increased anthropogenic fluxes of $\mathrm{Hg}$ into some coastal area, ${ }^{\mathbf{4 1}}$ the input of terrigenous organic carbon is expected to be correlated with the anthropogenic $\mathrm{Hg}$ discharge into the Chinese Bohai Sea area. It could be further speculated that $\mathrm{IHg}$ accumulated in mollusks are probably associated with the land-based anthropogenic fluxes of $\mathrm{Hg}$ into this region. 


\subsection{Influence of lipid contents}

As an organic compound, $\mathrm{MeHg}$ has the potential of being accumulated in lipids. In this work, the lipid contents in all 92 mollusk samples collected in the year 2009 were determined (Table S1 $\dagger$ ). The lipid contents of selected mollusks were in the range 1.98-18.8\% (d.w.). Ost, having the highest levels of $\mathrm{THg}$ and $\mathrm{MeHg}$ among bivalve species, contained the highest lipid contents $(15.71 \pm 2.22 \%$, d.w.). On the contrary, the two gastropods Rap and Nev, showing the highest levels of $\mathrm{THg}$ and $\mathrm{MeHg}$, contained the lowest lipid content $(6.99 \pm 1.76 \%$ and $6.18 \pm 1.72 \%$, respectively).

The correlations between concentrations of $\mathrm{Hg}$ (including THg, MeHg and IHg) and lipid contents are shown in Fig. 5. Surprisingly, both $\mathrm{THg}$ and $\mathrm{MeHg}$ levels in mollusks were observed to slightly decrease with lipid contents, although both correlations were not significant (THg-lipid, $R=0.105, P=$ 0.759; MeHg-lipids, $R=0.456, P=0.159$ ). Differently, the concentrations of $\mathrm{IHg}$ had a significantly positive correlation with lipid contents $(R=0.656, P<0.05)$. These results were obviously different from the previous report on the bioaccumulation of $\mathrm{MeHg}$ in fish, in which the levels of organic mercury were found to be significantly correlated with lipid contents. ${ }^{42}$ In order to find out the possible reasons for this, polynomial regression was further conducted between concentrations of $\mathrm{THg}$ and $\mathrm{MeHg}$ and lipid contents (Fig. 5 and S7 $†$ ). It was found that the polynomial correlations between both $\mathrm{MeHg}$ $(R=0.734, P<0.05$, Fig. 5) and THg $(R=0.629, P=0.133$, Fig. S7†) concentrations and lipid contents were much more significant than the linear regression. This could be explained by the differences in mollusk species used in this study. As shown in Table $\mathrm{S} 1, \uparrow$ the two gastropods were obviously different from the bivalve species, containing the lowest lipid contents, but the highest concentrations of $\mathrm{THg}$ and $\mathrm{MeHg}$. Mac had relatively lower lipid contents but relatively higher $\mathrm{Hg}$ concentrations as well. Including these three species (Rap, Nev and $\mathrm{Mac}$ ) in the calculation dismissed the significant positive linear relationship between concentrations of $\mathrm{THg}$ and $\mathrm{MeHg}$ and lipid contents.

According to the above discussion, the gastropods had the highest TLs, as well as the highest $\mathrm{THg}$ and $\mathrm{MeHg}$ concentrations. This indicates that trophic transfer plays the dominant role in the accumulation of $\mathrm{Hg}$ among different mollusk species, while lipid contents contribute to the dissolution of $\mathrm{MeHg}$ in mollusks. The significant positive linear correlations between $\mathrm{Hg}$ concentrations and lipid contents could not be found in different TLs of mollusks, although they have been confirmed in the same or similar species of fish. ${ }^{42}$ It needs to be mentioned that the differences in the strength of interactions between $\mathrm{Hg}$ species and proteins via sulfhydryl groups may also contribute to the capability of $\mathrm{Hg}$ accumulation in these mollusk species. Hence, protein content in mollusks could have an effect on the accumulation of $\mathrm{Hg}$, particularly $\mathrm{MeHg}$ since $\mathrm{MeHg}$ is known to have the highest ability of binding with proteins. ${ }^{43}$ As reported, $\mathrm{MeHg}$ is bound to myofibrillar proteins in fish muscles and correlated with muscle protein levels. ${ }^{\mathbf{4 4 , 4 5}}$ In addition, the effect of selenium on $\mathrm{MeHg}$ accumulation could be another possible factor, because recent studies have found that selenium can reduce the accumulation of $\mathrm{MeHg}$ and
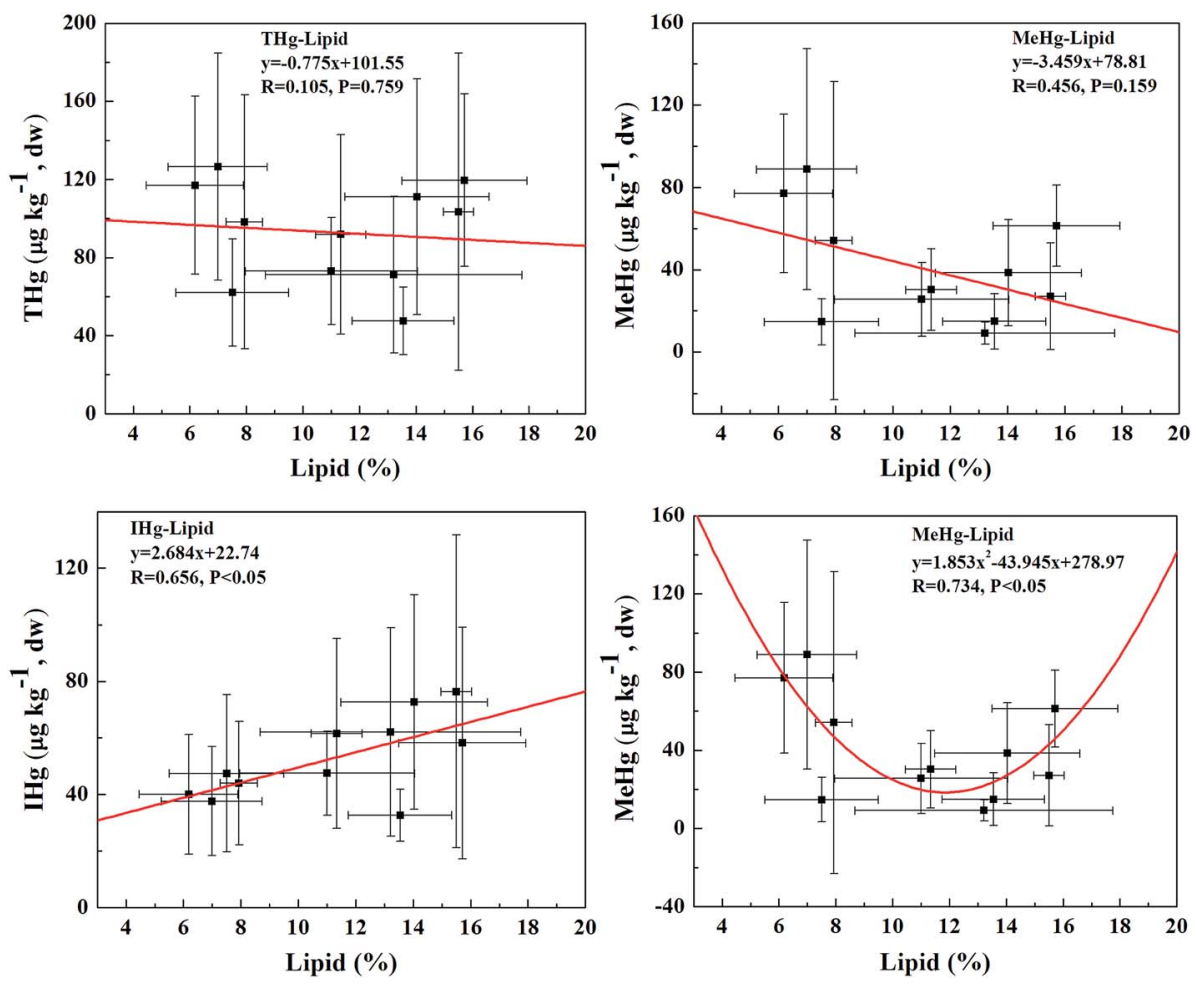

Fig. 5 Relations between concentrations of $\mathrm{Hg}(\mathrm{THg}, \mathrm{MeHg}$ and $\mathrm{IHg}$ ) and lipid content. 
enhance the elimination of $\mathrm{MeHg}$ in fish by decomposing $\mathrm{MeHg}$ into inorganic mercury selenide. ${ }^{46,47}$

\subsection{Potential application for $\mathrm{Hg}$ monitoring}

Since mollusks are widespread filter-feeding organisms and easily identified and collected, they have been employed for almost 30 years in the Mussel Watch Program (MWP) in the USA to monitor the contamination of trace metals and organic pollutants. Expensive and complex off-shore sampling design could be avoided using mollusks as indicators. ${ }^{48}$ The program has now been extended to other countries including China in the Asia-Pacific Mussel Watch Program (APMWP). ${ }^{4-50}$ Unfortunately, mollusks were seldom used to elucidate the spatial and temporal variations of $\mathrm{Hg}$ contamination, especially for Chinese Sea areas.

Numerous recognized species of mollusks that are highly diverse in body size, structure and feeding habit, have different abilities to accumulate $\mathrm{Hg}$. Mollusks are widespread in the coastal regions of China, including the Chinese Bohai Sea area. Therefore, it is practicable to investigate whether mollusks could be applied as potential bioindicator for long-term monitoring of $\mathrm{Hg}$ pollution in Chinese coastal regions. Ost and Myt have been found to be more suitable indicators for contamination of some POPs than other mollusk species..$^{25,33,34}$ Mya was most sensitive to organotin, in particular tributyltin, and was therefore an appropriate indicator for the contamination of organotin compounds. ${ }^{51}$ The possibility of using these mollusk species as bioindicators for $\mathrm{Hg}$ pollution in the Chinese Bohai Sea was evaluated in this study.

Among the 11 mollusk species, the two gastropods Nev and Rap contained the highest levels of $\mathrm{THg}$ and $\mathrm{MeHg}$, the highest TLs, and the lowest lipid contents. The bivalve Ost had the next highest concentrations of $\mathrm{THg}$ and $\mathrm{MeHg}$, the mid-level TLs, and the highest lipid contents. Referring to the reported concentration of $\mathrm{Hg}$ in the Bohai Sea water ${ }^{52,53}$ and the average concentration of $\mathrm{THg}$ in 29 surface sediments collected from the Bohai Sea, the bioaccumulation factors (BAFs) for $\mathrm{THg}$ and $\mathrm{MeHg}$ in each mollusk species were calculated (Table 2). The BAFs from water to mollusks (BAFs-W) were found to be in the ranges of 10 100-170 800 for $\mathrm{THg}$ and 31 800-4 477300 for $\mathrm{MeHg}$. The BAFs from sediment to mollusks (BAFs-S) were in the range 0.7-11.9 for $\mathrm{THg}$. Obviously, the BAFs were the highest in Rap, with BAFs-W ranging from 20000 to 170800 for THg and from 216700 to 4477300 for $\mathrm{MeHg}$ and BAFs-S ranging from 1.4 to 11.9 for THg. Therefore, Rap had relatively high abilities in accumulating $\mathrm{Hg}$ from seawater and sediment and would have sufficient sensitivity to reflect the extent of $\mathrm{Hg}$ contamination.

The one-way ANOVA and hierarchical cluster analysis were adopted to assess the data set of both $\mathrm{THg}$ and $\mathrm{MeHg}$. The results showed that Rap was significantly different from other mollusk species in the bioaccumulation of both $\mathrm{THg}$ and $\mathrm{MeHg}$ $(P<0.01$, one-way ANOVA; Fig. S8 $\dagger)$. Moreover, Rap was widespread gastropod specie around Chinese Bohai Sea area, had strong reproducibility under natural conditions and was easily collected from coastal waters every year. Therefore, Rap could be used as a potential bioindicator for $\mathrm{Hg}$ monitoring in the Chinese Bohai Sea. In addition, our previous studies in 2002 found that Rap also showed the highest capacity of accumulating Cd (ref. 7) and significant correlations existed among concentrations of $\mathrm{Cu}, \mathrm{Zn} \mathrm{Cd}$ and $\mathrm{Hg}$ in mollusks. ${ }^{54}$ Accumulation of Cd in mollusks of the coastal US were found to be linked to salinity and upwelling phenomenon in coastal waters. ${ }^{55}$ Therefore, Rap may be used to investigate the accumulation of other heavy metals, such as Cd, and provide more information of heavy metal contamination.

Table 2 Bioaccumulation factors (BAFs) for THg and MeHg in the 11 mollusks species collected during 2007-2012

\begin{tabular}{|c|c|c|c|c|c|c|c|c|c|c|c|c|}
\hline & Amu & Chl & Cyc & Mac & Mer & Mya & Myt & Ost & Sca & $\mathrm{Nev}$ & Rap & Total \\
\hline$n$ & 38 & 33 & 32 & 25 & 56 & 16 & 30 & 40 & 43 & 35 & 83 & 431 \\
\hline Mean & 33.2 & 40.3 & 23.3 & 32.1 & 22.0 & 35.7 & 37.3 & 39.2 & 32.6 & 33.9 & 55.9 & 36.8 \\
\hline Median & 33.2 & 34.7 & 22.0 & 22.9 & 20.0 & 30.2 & 29.9 & 38.3 & 28.3 & 29.5 & 46.4 & 29.9 \\
\hline Min & 16.5 & 13.3 & 11.8 & 13.2 & 10.1 & 15.6 & 10.3 & 12.0 & 13.6 & 13.5 & 20.0 & 10.1 \\
\hline \multicolumn{13}{|c|}{ BAFs-W $\left(\times 10^{3}\right)$ for $\mathrm{MeHg}\left(\mathrm{MeHg} \text { concentration in seawater: } 6.6 \times 10^{-5} \mu \mathrm{g} \mathrm{L}^{-1}\right)^{c}$} \\
\hline Mean & 542.4 & 586.4 & 307.6 & 493.9 & 337.9 & 516.7 & 303.0 & 698.5 & 290.9 & 760.6 & 1554.5 & 683.3 \\
\hline Median & 456.1 & 521.2 & 290.9 & 256.1 & 263.6 & 387.9 & 218.2 & 647.0 & 231.8 & 668.2 & 1266.7 & 445.5 \\
\hline Min & 137.9 & 145.5 & 83.3 & 83.3 & 53.0 & 112.1 & 39.4 & 192.4 & 31.8 & 187.9 & 216.7 & 31.8 \\
\hline Max & 1836.4 & 1372.7 & 863.6 & 2572.7 & 904.5 & 1445.5 & 975.8 & 1477.3 & 1583.3 & 2101.5 & 4477.3 & 4477.3 \\
\hline Max & 5.9 & 6.3 & 3.4 & 5.3 & 3.6 & 5.6 & 7.1 & 6.3 & 5.5 & 6.7 & 11.9 & 11.9 \\
\hline
\end{tabular}

${ }^{a}$ BAFs-W, BAFs from water to mollusks; BAFs-S, BAFs from sediment to mollusks. ${ }^{b}$ Data from ref. $52 .{ }^{c}$ Data from ref. 53. 


\section{Conclusion}

This study found significant positive correlations between $\mathrm{THg}$ and $\mathrm{MeHg}$ contents and trophic levels (TLs), and demonstrated the biomagnification of $\mathrm{MeHg}$ and growth dilution of $\mathrm{IHg}$ in the trophic transfer of low trophic level mollusks. Although lipid contents were reported to have significant correlations with $\mathrm{Hg}$ concentrations in the same or similar species of fish, TLS showed more effect on $\mathrm{Hg}$ levels in mollusks than lipid contents. Rapana venosa (Rap) had relatively high abilities in accumulating $\mathrm{Hg}$ ( $\mathrm{MeHg}$ in particular) from seawater and sediment and showed sufficient sensitivity to reflect the extent of $\mathrm{Hg}$ contamination. Therefore, Rap could be applied as a potential bioindicator for $\mathrm{Hg}$ pollution monitoring in the coastal regions of China. The results could help us to better understand the $\mathrm{Hg}$ uptake and transfer within marine food webs. However, laboratory culture and exposure test will be needed to identify the source and accumulation pathway of $\mathrm{MeHg}$ in mollusks and also to further investigate the fundamental reasons why Rap had high accumulation abilities for $\mathrm{Hg}$, such as genetic constitution.

\section{Acknowledgements}

This work was supported by the National Basic Research Program of China (2013CB430004), the National Natural Science Foundation of China (41422306 and 21120102040), the Strategic Priority Research Program of the Chinese Academy of Sciences (XDB14010400), and the Young Scientists Fund of RCEES (RCEES-QN-20130007F).

\section{References}

1 V. L. S. Louis, A. E. Derocher, I. Stirling, J. A. Graydon, C. Lee, E. Jocksch, E. Richardson, S. Ghorpade, A. K. Kwan, J. L. Kirk, I. Lehnherr and H. K. Swanson, Environ. Sci. Technol., 2011, 45, 5922-5928.

2 G. Stern and R. Macdonald, Environ. Sci. Technol., 2005, 39, 4707-4713.

3 J. P. Cheng, L. L. Gao, W. C. Zhao, X. J. Liu, M. Sakamoto and W. H. Wang, Sci. Total Environ., 2009, 407, 2625-2630.

4 Y. Lin, R. Vogt and T. Larssen, Environ. Toxicol. Chem., 2012, 31, 2431-2444.

5 K. Pan and W. X. Wang, Sci. Total Environ., 2012, 421-422, 316.

6 J. W. Farrington, E. D. Goldberg, R. W. Risebrough, J. H. Martin and V. T. U. S. Bowen, Environ. Sci. Technol., 1983, 17, 490-496.

7 L. N. Liang, B. He, G. B. Jiang, Y. D. Chen and Z. W. Yao, Sci. Total Environ., 2004, 324, 105-113.

8 K. L. Foster, G. A. Stern, M. A. Pazerniuk, B. Hickie, W. Walkusz, F. Y. Wang and R. W. Macdonald, Environ. Sci. Technol., 2012, 46, 12952-12959.

9 WHO (World Health Organization), Environmental Health Criteria \#1: Mercury, Geneva, 1976.

10 WHO (World Health Organization), Environmental Health Criteria \#101: Methylmercury, Geneva, 1990.
11 E. D. Stein, Y. Cohen and A. M. Winer, Crit. Rev. Environ. Sci. Technol., 1996, 26, 1-43.

12 I. Andersson, H. Parkman and A. Jernelov, Limnologica, 1990, 20, 347.

13 R. E. Farrell, J. J. Germida and P. M. Huang, Appl. Environ. Microbiol., 1990, 56, 3006.

14 H. U. Riisgard and S. Hansen, Mar. Ecol.: Prog. Ser., 1990, 62, 259.

15 T. G. Seixas, I. Moreira, S. Siciliano, O. Malm and H. A. Kehrig, Bull. Environ. Contam. Toxicol., 2014, 92, 274278.

16 G. L. Lescord, K. A. Kidd, J. L. Kirk, N. J. O'Driscoll, X. Wang and D. C. G. Muir, Sci. Total Environ., 2015, 509-510, 195205.

17 M. G. Clayden, L. M. Arsenault, K. A. Kidd, N. J. O'Driscoll and M. L. Mallory, Sci. Total Environ., 2015, 509-510, 206215.

18 E. Kim, H. Kim, K. Shin, M. Kim, S. R. Kundu, B. Lee and S. Han, Environ. Toxicol. Chem., 2012, 31, 1254-1263.

19 A. T. Fisk, K. A. Hobson and R. J. Norstrom, Environ. Sci. Technol., 2001, 35, 732-738.

20 H. Hop, K. Borgå, G. W. Gabrielsen, L. Kleivane and J. U. Skaare, Environ. Sci. Technol., 2002, 36, 2589-2597.

21 X. S. Jin, X. J. Shan, X. S. Li, J. Wang, Y. Cui and T. Zuo, Earth Sci., 2013, 56, 366-374.

22 Z. Z. Sun, J. Zhou, Z. L. Zhao, Y. F. Xu, W. B. Gao, S. Zhuang, B. Chen, J. Wang, W. Yan and C. H. Wang, Mar. Sci., 2012, 36, 44-53.

23 USEPA, Method 7473: Mercury in Solids and Solutions by Thermal Decomposition Amalgamation, and Atomic Absorption Spectrophotometry, 2007.

24 USEPA, Method 1630: Methyl Mercury in Water by Distillation, Aqueous Ethylation, Purge and Trap, and CVAFS. Draft January 2001, U.S. Environmental Protection Agency, Office of Water, Office of Science and Technology Engineering and Analysis Division (4303), Washington, DC 20460, 2001, pp. 1-41.

25 B. Yuan, T. Wang, N. L. Zhu, K. G. Zhang, L. X. Zeng, J. J. Fu, Y. W. Wang and G. B. Jiang, Environ. Sci. Technol., 2012, 46, 6489-6496.

26 CNSA (Chinese National Standard Agency), Maximum levels of contaminants in foods (in Chinese), GB 2762-2012, 2012.

27 J. P. Coelho, M. Rosa, E. Pereira, A. Duarte and M. A. Pardal, Estuarine, Coastal Shelf Sci., 2006, 69, 629-635.

28 J. P. Coelho, A. C. Duarte, M. A. Pardal and M. E. Pereira, Ecol. Indic., 2014, 46, 447-453.

29 L. N. Liang, J. B. Shi, B. He, G. B. Jiang and C. G. Yuan, J. Agric. Food Chem., 2003, 51, 7373-7378.

30 Y. W. Wang, X. M. Li, A. Li, T. Wang, Q. H. Zhang, P. Wang, J. J. Fu and G. B. Jiang, Environ. Sci. Technol., 2007, 41, 60266032.

31 Y. Wan, J. Y. Hu, L. H. An, W. An, M. Yang, M. Itoh, T. Hattori and S. Tao, Chin. Sci. Bull., 2005, 50, 1021-1025.

32 Y. Wan, J. Y. Hu, M. Yang, L. H. An, W. An, X. H. Jin, T. Hattori, S. Masunaga and M. Itoh, Environ. Sci. Technol., 2005, 39, 2417-2425.

33 Y. W. Wang, T. Wang, A. Li, J. J. Fu, P. Wang, Q. H. Zhang and G. B. Jiang, Environ. Sci. Technol., 2008, 42, 7159-7165. 
34 N. L. Zhu, A. Li, T. Wang, P. Wang, G. B. Qu, T. Ruan, J. J. Fu, B. Yuan, L. X. Zeng, Y. W. Wang and G. B. Jiang, Environ. Sci. Technol., 2012, 46, 7174-7181.

35 A. Sobek, G. Cornelissen, P. Tiselius and O. Gustafsson, Environ. Sci. Technol., 2006, 40, 6703-6708.

36 D. M. Schell, B. A. Barnett and K. A. Vinette, Mar. Ecol.: Prog. Ser., 1998, 162, 11-23.

37 S. D. Siciliano, N. J. O'Driscoll and R. Tordon, et al., Environ. Sci. Technol., 2005, 39, 1071-1077.

38 V. Perrot, M. V. Pastukhov, V. N. Epov, S. Husted, O. F. X. Donard and D. Amouroux, Environ. Sci. Technol., 2012, 46, 5902-5911.

39 Z. Z. A. Kuzyk, R. W. Macdonald, J.-É. Tremblay and G. A. Stern, Cont. Shelf Res., 2010, 30, 163-176.

40 S. W. Sun, M.S. Thesis, Ocean University of China, 2012.

41 A. Hare, G. A. Stern, Z. Z. A. Kuzyk, R. Macdonald, S. C. Johannessen and F. Wang, Environ. Sci. Technol., 2010, 44, 5805-5811.

42 M. Pal and M. Ghosh, Environ. Monit. Assess., 2013, 185, 3137.

43 M. Xu, X. W. Yan, Q. Q. Xie, L. M. Yang and Q. Q. Wang, Anal. Chem., 2010, 82, 1616-1620.

44 Y. S. Gong, D. P. Krabbenhoft, L. P. Ren, B. Egelandsdal and M. P. Richards, J. Agric. Food Chem., 2011, 59, 11050-11057.
45 D. J. Kutscher, A. Sanz-Medel and J. Bettmer, Metallomics, 2012, 4, 807-813.

46 D. Y. Yang, Y. W. Chen, J. M. Gunn and N. Belzile, Environ. Rev., 2008, 16, 71-92.

47 H. Amlund, A. Lundebye, D. Boyle and S. Ellingsen, Aquat. Toxicol., 2015, 158, 211-217.

48 E. D. Goldberg, Mar. Pollut. Bull., 1975, 6, 111.

49 K. L. Kimbrough, W. E. Johnson, G. G. Lauenstein, J. D. Christensen and D. A. Apeti, MDNOAA technical memorandum NOS NCCOS, Silver Spring, 2008, vol. 74, p. 105.

50 I. Monirith, D. Ueno, S. Takahashi, H. Nakata, A. Sudaryanto and A. Subramanian, et al., Mar. Pollut. Bull., 2003, 46, 281300.

51 Q. F. Zhou, J. B. Zhang, J. J. Fu, J. B. Shi and G. B. Jiang, Anal. Chim. Acta, 2008, 606, 135-150.

52 Z. J. Ci, X. S. Zhang, Z. W. Wang and Z. C. Niu, Mar. Chem., 2011, 126, 250-255.

53 S. F. Wang, Y. F. Jia, S. Y. Wang, X. Wang, H. Wang, Z. X. Zhao and B. Z. Liu, Appl. Geochem., 2009, 24, 1702-1711.

54 Y. W. Wang, L. N. Liang, J. B. Shi and G. B. Jiang, Environ. Int., 2005, 31, 1103-1113.

55 D. A. Apeti, G. G. Lauenstein and G. F. Riedel, Mar. Pollut. Bull., 2009, 58, 1016-1024. 